\title{
Front Matter: Volume 11834
}

, "Front Matter: Volume 11834," Proc. SPIE 11834, Laser Communication and Propagation through the Atmosphere and Oceans X, 1183401 (8 September 2021); doi: $10.1117 / 12.2606661$

SPIE Event: SPIE Optical Engineering + Applications, 2021, San Diego, California, SPIE. United States 


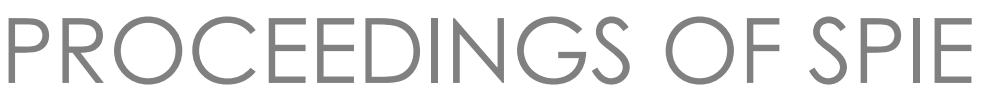

\section{Laser Communication and Propagation through the Atmosphere and Oceans $X$}

Jaime A. Anguita

Jeremy P. Bos

David T. Wayne

Editors

1-5 August 2021

San Diego, California, United States

Sponsored and Published by

SPIE

Volume 11834 
The papers in this volume were part of the technical conference cited on the cover and title page. Papers were selected and subject to review by the editors and conference program committee. Some conference presentations may not be available for publication. Additional papers and presentation recordings may be available online in the SPIE Digital Library at SPIEDigitalLibrary.org.

The papers reflect the work and thoughts of the authors and are published herein as submitted. The publisher is not responsible for the validity of the information or for any outcomes resulting from reliance thereon.

Please use the following format to cite material from these proceedings:

Author(s), "Title of Paper," in Laser Communication and Propagation through the Atmosphere and Oceans X, edited by Jaime A. Anguita, Jeremy P. Bos, David T. Wayne, Proc. of SPIE 11834, Sevendigit Article CID Number (DD/MM/YYYY); (DOI URL).

ISSN: 0277-786X

ISSN: 1996-756X (electronic)

ISBN: 9781510645066

ISBN: 9781510645073 (electronic)

Published by

SPIE

P.O. Box 10, Bellingham, Washington 98227-0010 USA

Telephone +1 3606763290 (Pacific Time)

SPIE.org

Copyright @ 2021 Society of Photo-Optical Instrumentation Engineers (SPIE).

Copying of material in this book for internal or personal use, or for the internal or personal use of specific clients, beyond the fair use provisions granted by the U.S. Copyright Law is authorized by SPIE subject to payment of fees. To obtain permission to use and share articles in this volume, visit Copyright Clearance Center at copyright.com. Other copying for republication, resale, advertising or promotion, or any form of systematic or multiple reproduction of any material in this book is prohibited except with permission in writing from the publisher.

Printed in the United States of America by Curran Associates, Inc., under license from SPIE.

Publication of record for individual papers is online in the SPIE Digital Library.

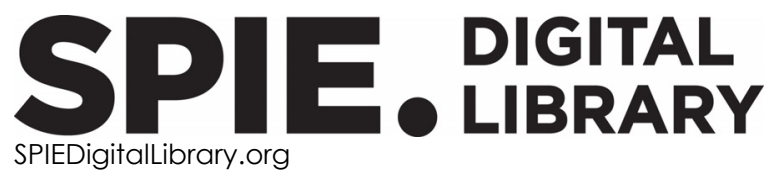

Paper Numbering: A unique citation identifier (CID) number is assigned to each article in the Proceedings of SPIE at the time of publication. Utilization of CIDs allows articles to be fully citable as soon as they are published online, and connects the same identifier to all online and print versions of the publication. SPIE uses a seven-digit CID article numbering system structured as follows:

- The first five digits correspond to the SPIE volume number.

- The last two digits indicate publication order within the volume using a Base 36 numbering system employing both numerals and letters. These two-number sets start with 00, 01, 02, 03, 04, 05, 06, 07, 08, 09, 0A, OB ... 0Z, followed by 10-1Z, 20-2Z, etc. The CID Number appears on each page of the manuscript. 


\section{Contents}

\section{EXPERIMENTS}

1183402 Evaluation of instruments for turbulence measurements at 1 km and 13.5 km ranges [11834-4]

$1183404 \quad$ Extended analysis of atmospheric refiaction effects captured by time-lapse imaging: longtem trends and machine leaming image shift predic tion [11834-1]

1183405 Experimental validation and design feasibility of a compact interferometric refiactive index struc ture constant measurement sensor for atmospheric turbulence characterization [11834-2]

1183406 Optical propagation across the Chesapeake Bay: comparison of experiment to theory (Invited Paper) [11834-3]

FSO

$1183407 \quad$ Free-space, optical time transfer through a water tank [11834-11]

1183408 A 30-cm Z-process silic on carbide off-axis parabola for lasercom telescope [11834-8]

1183409 Hardware emulation of satellite-to-ground APD-based FSO downlink affected by atmospheric turbulence-induced fading [11834-9]

$11834 \mathrm{OB} \quad$ Extemal sensor arays for assisting pointing, tracking, and acquisition in FSO communication [11834-13]

MITIGATION METHODS

11834 OD Digital adaptive optics for turbulence mitigation [11834-17]

$11834 \mathrm{OE} \quad$ Leaming-based mitigation of atmospheric turbulence effects on high-power laser beams in a simulated environment [11834-14]

11834 OF Wavefront sensing for terrestrial, underwater, and space-bome free-space optical communications (Invited Paper) [11834-16]

OAM

11834 OG Performance of turbulence-impaired dense OAM constellations for data modulation [11834-18] 
$11834 \mathrm{OH} \quad$ Classification of multiple-state OAM superpositions using convolutional neural networks [11834-19]

$11834 \mathrm{Ol} \quad$ Machine leaming identification of multiple-state OAM superpositions detected with spatial mode sensors [11834-20]

THEORY AND SIMULATION

11834 0] Comparison of single line and broad-spectrum Gaussian beam propagation through turbulence [11834-24]

11834 OK The azimuthal spectrum of common transmittance functions and random media [11834-26]

$11834 \mathrm{OL} \quad$ Simulation of $\mathrm{lm}$-Bessel beam propagation through time-correlated atmospheric turbulence [11834-27]

11834 OM Statistics of turbulence-induced laser inadiance fluctuations: impact of receiveraperture size [11834-21]

11834 ON Simulating a $980 \mathrm{~nm}$ laser beam propagation through humid air[11834-22]

1183400 Semi-analytic simulation of optical wave propagation through turbulence with arbitrary phase screen placement (Invited Paper) [11834-25]

11834 OP Beam trajectory studies of diumal refraction effects for a near-ground path involving numerical weather prediction and time-lapse imaging measurements [11834-23]

ATMOSPHERIC CHARACTERIZATION: J OINTSESSION WTH 11834 AND 11836

11834 OQ Nonlinear dynamics of the laser spot size and pulse duration in turbulence [11834-28]

11834 OS Statistics of optical turbulence from multi-year sonic anemometer-themometer obsenations at a semi-arid region: effects of aerosols and atmospheric boundary layer dynamics [11834-30]

11834 0T Vertical profiles of turbulence measured with a Rayleigh beacon [11834-31]

\section{POSTER SESSION}

11834 OV Inner scale of turbulence as derived from NAVSLaM and applied to measurements of scintillation [11834-33]

11834 OW Bit emor rate of free-space optical communication systems through exponentiated Weibull turbulent channels: impact of atmospheric aerosol induced waming [11834-35] 